\title{
A Tentative Study on Thomas Hardy's Fatalism in The Return of the Native
}

\author{
Xue Zhao \\ English Language and Culture Department, Teachers' College of Beijing Union University, Beijing, China

\begin{abstract}
Thomas Hardy, the most influential novelist in British literature is famous for the pessimism and fatalism in his works. This paper mainly discusses the characters in The Return of the Native to probe into Hardy's fatalism through his keen observation and skillful writing of the description of the tragedy. Instead of
\end{abstract} \\ the overwhelming pessimism, the author also sheds a hope for the human beings.
}

Index Terms - The Return of the Native, fatalism, destiny

\section{INTRODUCTION}

The Return of the Native is the first mature novel written by Thomas Hardy in 1878. From the first publication of his first novel, it aroused great attention. Not so much because it achieves great artistic excellence in painstaking character-portrayal and the vivid descriptions of nature and a locality and of the rustic folk, but because it is the novel embraces all the basic and essential points of the novelist's philosophy (Jia Chen, 1996). Hardy's critics accused him of being overwhelmingly pessimistic about human's position in the wild background of nature. The Return of the Native was regarded as the representative works which showed the dominance of Nature over Man, stressing the powerless man's against the infinity of nature.

As Lord David Cecil (2000) remarked in Hardy, the Novelist: "In all his fiction, The Return of Native is the most Darwinian novel in the emphasis he placed on the bleak struggle for survival in the blind forces controlling human destiny" (p. 23).

With the same tone, Tony Tanner (1998) presented: "Like the great tragedies of the fifth century, Athens and Elizabethan England, Hardy's character and environment of The Return of the Native convey a strong sense of fatalism, a view that in life human actions have been predetermined either by the very nature of things, or by God, or by Fate" (p. 425).

This paper intends to give a glimpse of the Hardy's philosophical view of life and fate so as to explore whether Hardy is as pessimistic as what all the above critics pointed out, how Hardy becomes so despondent about human beings in the vast nature, in their struggle against fate, and what Hardy's philosophical views about this exactly is.

\section{INFLUENCE OF DARWINISM ON HARDY}

With the study of Hardy's notes and autobiography, it is clear that he was strongly influenced by Darwinism. No other single book made a more significant immediate impact on him than The Origin of Species. However, different from his contemporaries who advocated the progress of their time, Hardy has originality of his own pessimistic view of human beings who were extremely helpless and smallness in a wild universe which was indifferent to human feelings and ethical aspirations Darwinism prompted him to set images of human life against the background of vast nature.

Concerning nature, Hardy also pointedly stressed that nature is immoral and indifferent to human beings who are temporarily lived in it. In his autobiography, for example, he consequently expressed his sense of the losing struggle of individuals against the forces of Nature that gradually destroy them. Working behind the pressures is Fate. "It is not his fault," he said, "that they do not suffer; nor is it their fault either they are pushed and finally pinned down by the overwhelming forces of fate" (Schweik, 2000, p. 62).

This view can also find good expressions Edinburgh Review in 1886 where Hardy showed his admiration of Hugo. Hugo's theme is the predestined fate of human existence, the struggle between man and destiny; he insists upon the compulsion of circumstances, the tragic force that overrides the human will” (F. B. Pinion, 1977, p. 37).

Among Hardy's so many works, of earlier fictions, The Return of the Native most distinctly embodies those concerns. Hardy (1975) depicts Clym Yeobright whose ideal physical beauty is incompatible with growth of fellow-feeling and a full sense of the coil of things (p.138); He also describes Eustacia Vye's frustrated longings for hopeless ideals; These convey the alienation of thinking and feeling that humans in a universe which is indifferent to their ideals and sensitivities. It suggests the hostile nature of the heath against these characters. Critics, as John Goode, referred to Hardy's (1975) themes in this novel as "expressing a fatalism view of life; that is to say, a view of life which depicts human actions as subject to the control of an impersonal force, perhaps called Destiny or Fate. Obey it, men survive; otherwise, die" (p. 39).

In The Return of the Native, Hardy specialized nature, the vast force in the Egdon heath where most of the actions of 
the story take place and which he was constantly concerned to emphasis its intense natural power, generalized as the indifferent universe.

\section{CHARACTERS UNDER THE INFLUENCE OF FATALISM}

\section{A. Dominance of Nature over Man}

From the first page, the Heath is established as an environment larger, older and stronger than its inhabitants are. It is depicted as a backdrop with boundless darkness and primitive forces. It is an immortal place. It is described in the Domesolay Book nine hundred years as it is today. As its inhabitants live and die, it keeps the same. Here Egdon Heath does not simply serve as the backdrop for the story, but a complex symbol of indifferent nature, a blind eternal force that governs the all. Hardy dramatized to present humankind against a background of vast impersonal force. In contrast with the Heath, which becomes an embodiment of the powerful force, is the man itself: mortal and vulnerable, selfish, and always looking to advance his place in the world (Robin Mayhead 34) ${ }^{10}$.

This novel is to show the predominance of nature over man. This view is shared by the character of Eustacia Vye, who rebels against these inevitable, leading to her downfall, and Clym Yeobright, who tries to change the heath only ending changed by nature and lonely living in the heath. All these explicitly show Hardy's pessimistic view of human being's struggle against nature.

\section{B. Eustacia Who Constantly Rebels Against Life but Receives Failure}

Eustacia, one of the main characters dreams to leave the heath where she feels she doesn't belong; however, it is also where she is determined to stay until death. In the novel, Eustacia is introduced as a native of the fashionable seaside resort of Budmouth. Her non-English father gives her a slightly exotic appearance, which makes her a little bit different from the others thus is regarded as an outsider on Egdon Heath.

However, fate makes her come to heath, which she says despairingly and prophetically, is "my cross, my shame, and will be my death" (Hardy, p. 91). However, she extremely hates the heath and is eager to leave here. Constantly building up memories of her childhood in Budmouth into a fantasy of the delights of a town, for several years, she has been starved of what she calls 'life': 'life---music, poetry, passion, war, and all the beating and pulsing that are going o in the great arteries of the world' (Hardy, p.333-4). Rebellious by nature she refuses to try to come to terms with the heath, thinking herself superior to the people of Edgon and holding arrogantly aloof. All her desires lie in dreams of escape.

Suddenly an opportunity comes in the form of a clever young man from Paris. In her eyes, the young man Clym is more than a human being but a key to unlock the glittering world of the dream of her city. She dresses as a male mummer and roams the heath so frequently in an attempt to meet Clym by accident because she thinks he will give her a reassurance that his return to Paris is a possibility. With the thought that this man can change her fate living on the heath, Eustacia marries the man---to say exactly, to her dream.

However, fate has determined her to pin on the Heath. Therefore, any effort of her escape from nature is in vain. After her marriage, disaster inevitably follows. The first thing that makes her disappointed is that her knight who she thinks will bring her to her dreaming-city, decides to stay in nature because he regards himself as the son of nature. However, so conceited she is, she thinks she has a decisive influence on her husband that can change his mind. As a consequence, she is even willing to abandon her high economic status and move to a small house, which she fails to conceive it will last for quite long time. She has thought that they would leave there to Paris and begins a glamorous life.

By a cruel irony of fate, despite all of her painstaking efforts, Clym turns out to be the only man that cannot fulfil her desires since Clym chooses to stay at the heath and educate the uneducated, instead of leaving the heath. Even so, Eustacia still has hopes of Paris until her husband goes blind. While to Eustacia, purblind Clym is now an unambitious man and a fallen idol; far from being the knight who she had once idealized her lover. Now Clym has degraded into a mere workman. Seeing her husband happily singing while working, she is totally in despair. Until that moment, she suddenly realizes that they will never leave the heath.

Making painstaking efforts only to discover that the one man whom she has thought to take her escape is just the opposite; Crazed, Eustacia leaves her husband. However, if Eustacia could have lived as the other natives and accepted the life on the heath, if she would have been obedient to her fate, her life will be completely different.

Yet, Eustacia does not. With the disillusionment of her husband to escape from the native, she changes to Wildeve by abusing her attraction to him. Yet, fate is destiny that couldn't be changed by the individuals. So, fighting against the inevitable, the only result of Eustacia is death when she tries to escape with Wildeve from the control of nature, the fate.

Just before her drowning, she reveals her complain of her injustice fate and her impotence of rebelling against her fate:

How I have tried and tried to be a splendid woman, and how destiny has been against me!...I do not deserve my lot!...o, the cruelty of putting me into this ill-conceived world ! I was capable of much; but I have been injured, blighted, and crushed by things beyond my control! $\mathrm{O}$, how hard it is of heaven to devise such tortures for me, who have done no harm to heaven at all! (Hardy, p. 357)

Eustacia's view of herself as a victim of a cruel destiny is the echo of Hardy's pessimistic view of the useless rebellion against the unavoidable. 
Such is Eustacia who sacrifices her life to escape from fate, from the control of nature. She is a poor, trapped bird like so many of Hardy's heroines, a queen "without realms or hearts to queen it over" (Hardy, p.167). Too passionate for her good, she is forced to live on Egdon where "coldest and meanest kisses were at famine prices" until her death (Hardy, p.84). These portrayed Eustacia as a victim who falls into the web of inevitable fate which she desperately fights against but is finally punished by.

From there, we can get knowledge of Hardy's philosophical view about the sheer futility of individual's struggle against the cruel universe.

\section{Clym Who Intends to Change the Reality but Be Changed by It Finally}

Hardy's pessimistic and fatalistic views can also be well illustrated by Clym's characters and his relationships with the other characters. In the novel, he is depicted so unwoven with the heath in his boyhood that hardly anybody could look upon it without thinking of him (Hardy, p.174); Edgon "permeates" him "with its scenes, with its substance, and with is odors" (Hardy, p.172). With the conception that he is rooted in the heath, the native Clym, once highly regarded, could have much more chances to pursue a splendid life in the big city, but decisively gives up the worldly success and answers the call of his native land. However, everything between the two worlds ---Paris and the heath, are not just incompatible: there exists a deadly animosity between them like that between Edgon and 'civilization' (George Wotton, 1985, p. 116).

On his return from Paris, failed to make a right and realistic judgement of the reality, Clym is so ignorant that he even dreams of educating the workfolk without solving the problem of their poverty first. Therefore, there is a conflict between the heath and him. Of course, the result of human against nature and fate is undoubtedly known---he is fatefully destroyed.

In the treatment of this character who wants to change the forever nature, Hardy makes Clym exposed to a series of misfortunes, one blow after another. After the death of his mother, he returns to an extreme form of the guilt and remorse. At last, he is much more vulnerable, but he is not so frenzied to realize his dream to educate the heath person. Moreover, he is indulging in a barbarous satisfaction at the heath's resistance to cultivate and survive in the heath working and preaching.

Clym determines to give up all he gains in Paris and returns to his native land in order to change the heath in the way of bringing civilization to it. Trusted by his mother, he plans to be a teacher to educate the natives and live a happy marriage life. Yet, in the end, Clym only destroys all the three goals and is stripped of respect and trust, finally becomes a rootless itinerant in the heath.

Contrasted to Eustacia who rebels against nature and longs to escape from nature, Clym who returns here, only wants to improve and change the conditions in the heath. However, he still fails in the bout between human being and nature or fate.

From here, we can sense that Hardy was quite obviously trying to contrast the strong power of fate symbolized by the Egdon heath with the insignificance of man and to show the utter helplessness before the inevitable. He believed that human being couldn't change the inevitable; conversely it is human beings who are changed by nature. These can be illustrated by Clym's original intention and final ending.

\section{Minor Characters}

The well-known happy character in this novel is regarded as Thomason. Most reader must presume she should lead a happy life because she always obeys the fate. However, it is not the intention of Hardy to create a happy Thomasin but to create this character in the belief that the world needs its Thomasins---those who quietly accept the tragic inevitability of things (Rosemary Sumner, 1981, p. 55). In addition, in fact, it is not Hardy's original idea to make such kind of happy end of this character---marrying her lover. Hardy added a tantalizing note in the 1912 edition explaining that the Thomasin-Diggory marriage was not part of his original conception of the novel and that was forced by the public demand for a happy ending (Sumner, p. 54).

We can say that Thomason is the model woman created by Hardy. However, although she always obeys what gives her, carrying the fatalistic view of her life, her life is not so quite satisfactory. She is too obedient to what life orders her to do. Her obedience to her fatalistic views pushes her dealing with the relationship with Wildeve. Although she knows there exists no real love between them, she still agrees to marry him. Because she realizes that if she does not marry him, inhabitants in the heath will gossip about her. However, their after-marriage life is not so satisfactory. Lonely at home, waiting for her husband dating with another woman, that is the life of the so-called model lady. Although in the end, she accepts his second marriage proposal with the following view: "I agreed to it... because I am a practical woman now. I do not believe in hearts at all. I would marry him under any circumstances..." (Hardy, p. 316). In the end, the good Thomason with her do-good husband has removed to the very fringe of the heath's reaches-of no account to it. Therefore, we can know that even the obedient one cannot easily find their happy life.

\section{CONCLUSION}

Hence, it is fully reflected in his novels that Hardy himself was strongly influenced by the pessimistic view that no matter how human beings put forward to change the fate, no matter how hard they make efforts to pursue happiness, to 
achieve ethical ideas, the results keep the same. Men are always the loser.

However, to say Hardy is completely pessimistic is not completely correct and justified. We can surprisingly find that he also carries some hope on human's struggle against nature, against fate. We can sense it from his creation of the death of Eustacia. Although dead for her dream, she dies peaceful and happy. Here on Eustacia this character, besides the mainstream of Hardy's pessimism, we can sense a little of the optimistic tendency of Hardy's view of human's struggle against fate.

Just as many critics, represented by Robin Mayhead, have pointed out, she is created as the Promethean and Byronic rebel who is 'emblematic of the feeling and infinite desire which rebel against inevitable limitation' (Hardy, p. 37). Hardy's intentional creation of this character represents his conflict mind towards human's struggle. Although in the whole, he is pessimistic towards fate, in the trivial details, we can be aware that he also pins hope on human's rebellion. It can be fully shown in the ending of Eustacia. In her death, Eustacia is happy and peaceful. It is very ironic that only death could bring her happiness and peace, and finally give her relief from the dejectedness of the heath. Her death must become a victory over life which has been always indifferent to human being's aspiration and ideals. From here, we can sense his sympathy towards the tragic resister who carries his hope in the struggle against the inevitable fate. Anyway, it cannot change Hardy's pessimistic view towards human being in the society, for in the end, Hardy still makes the rebellious heroine die which symbolizes the failure of human's attempt to rebel.

Besides, one thing must be mentioned that Hardy is not passively pessimistic. When a man living in the inevitable, although, he cannot change all, Hardy advocates Darwin's survive for the fittest. That is to say, whatever happens, human being should try to be adapted to the society, the change. This philosophical attitude towards human's existence can be fully expressed by Clym's final survive in the heath. His survive in the struggle of human against nature is due to his ability to constantly change his way of life to make himself fit to nature. He takes all of his successes and failures as they come because he knows everything in his life has been determined. With the notion that he is the son of the heath where he belongs, he thinks the life in Paris is not right for him, and he must return to his native heath. It seems like a birthright which symbolizes his root and identity although he is described as someone extraordinary from the birth time but at heart a man of the heath.

Again, when Clym is blinded, he is not destroyed by this mishap. Instead, he makes some changes in his lifestyle. Although he is an exceptional person, he doesn't care to become a furze-cutter as the other natives do. He even enjoys the job, as, "the monotony of his occupation soothed him, and was in itself a pleasure...his effort offered homely courses" (Hardy, p. 232). He enjoys his new work, which shows he is at peace with the nature. The adaptivity that Clym shows in his lifestyle reflects his notion of fatalism. This character represents Hardy's view that man should not be destroyed by nature, or helplessly give up, instead, he should actively accumulate himself to nature.

Analyzing the lives of these people in Return of the Native, we can find that life has been stern with all of them; Hardy is a severe writer, and his characters always have to struggle against the dour, unsmiling hostility of existence. In addition, the result is always that nature that symbolizes the force and fate overwhelms human being; and human being unchangeably obeys $\mathrm{t}$ nature. Jake Lothe (2000), pointed out that Hardy caught a pessimistic philosophy that accentuated the active part played by the mysterious force of external circumstances upon human lives (p. 115). From his point of view, there seems to be something mysterious in nature, something out of the control of the human power, but determines human fate and frustrates human desires. He advanced that "tragedy exhibits a state of things in the life of an individual which unavoidably causes desire of his to end in a catastrophe when carried out" (Garwood, 1911, p. 182). Anyway, Egdon will remain the same forever.

However, at the same time, we cannot neglect that although Hardy creates the lives of the characters assuredly be tragic, but for a tendency, he still is not over pessimistic. He does carry sympathy to the resister and pin hope on the human's struggle in nature. Instead of submitting to the fate, he advocated the active amalgamation and adaptation to nature that is manifest by Clym's flexible lifestyle.

Therefore, to sum up, by the comprehensive analyses of the main characters in The Return of The Native, it gives most explicit expression of Hardy's philosophical view on the human's fate. Reading this novel, we can justify Hardy's attitude towards human's struggle in nature. Despite the prevailing image of Hardy as a pessimist, there is ample evidence that he shared the guarded optimism of human being. The readers instead of depressed by the novel, can still see hope of our life in nature. "It (nature) was at present a place perfectly accordant with man's nature---neither ghastly, hateful, nor ugly: neither commonplace, unmeaning, nor tame” (Hardy, p. 33).

\section{REFERENCES}

[1] David, Cecil. (2000). Hardy the Novelist, quoted in Peter Widdowson, "Hardy and Critical Theory", in Dale Kramer eds., The Cambridge Companion, to Thomas Hardy. Shanghai: Shanghai Foreign Language Education Press, p. 23-24.

[2] Goode, John. (1988). Thomas Hardy, the Offensive Truth. United Kingdom: Basil Blackwell.

[3] Hardy, Thomas. (1975). The Return of the Native. London: The Macmillan Press LTD.

[4] Helen, Garwood. (1911). Thomas Hardy: An Illustration of the Philosophy of Schopenhauer. Philadelphia: John C. Winston Cooperation.

[5] Jia, Chen. (1996). A History of English Literature III. Beijing: The Commercial Press.

[6] Mayhead, Robin. (1978). Thomas Hardy, British Authors. Cambridge: Cambridge University Press.

[7] Pinion, F.B. (1977). Thomas Hardy: Art and Thought. London: The Macmillan Press LTD 
[8] Sumner, Rosemary. (1981). Thomas Hardy: Psychological Novelist. New York: St. Martin’s Press.

[9] Tony, Tanner. (1998). The Victorian Novel: Essays in Criticism. Hong Kong: Macmillan. D.

[10] Wotton, George. (1985). Thomas Hardy: Towards A Materialist Criticism. Ireland: Gill and Macmillan LT.

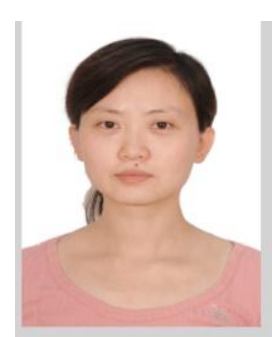

Xue Zhao was born in Tianjin, People's Republic of China in 1979. She received Master Degree of English Language and Literature from Beihang University in 2004, specialized in American literature.

From 2004, she has worked as an English Teacher at Teacher's College of BUU in Beijing. Currently she is an associate professor there. She has published several coursebooks and books in the field of American literature: Selective Readings of American Literature in $20^{\text {th }}$ century (Shanghai, China: Tongji University Press, 2018), Study of Deconstructive and Constructive Techniques and Functions in the Novels of Kunt Vonnegut (Shanghai, Donghua University Press, 2014), The Oedipus Paradox : Study of Paternal Characters and Authority in the Novels of John Irving (Shanghai, Donghua University Press, 2013). Her research interests and publications cover the areas of American Literature and TESOL, particularly Modern American Literature and the teaching of Chinese as a second for normal students. 